\title{
Factors Influencing Commercialization of Horticultural Crops Among Smallholder Farmers in Juba, South Sudan
}

\author{
Emmanuel A. Ater ${ }^{1 *} \quad$ Benjamin K. Mutai ${ }^{2}$ Hillary K. Bett ${ }^{2}$ \\ 1.School of Natural Resources and Environmental Studies, Department of Agriculture, University of Juba, \\ P.O. Box 82, South Sudan \\ 2. Department of Agricultural economics and Agribusiness Management, Egerton University \\ P.O. Box 536-20115 Nakuru, Kenya
}

This research was funded by the Center of Excellence for Sustainable Agriculture and Agribusiness Management (CESAAM)

\section{Abstract}

This paper aims at analyzing socio-economic and institutional factors influencing the commercialization of horticultural crops among smallholder farm households in Juba, South Sudan. The study adopted a multi-stage sampling technique to select a sample of 151 respondents. The survey was conducted using semi-structured questionnaires to collect primary data. The data collected were analyzed using descriptive statistics and a Tobit regression model by STATA analytical software. The results from descriptive statistics indicated that $77.48 \%$ of the farmers are female, $36.65 \%$ have access to land, $37.09 \%$ have access to education at the primary level, $96.69 \%$ have no access to market information, $74.17 \%$ do not have group membership and only $54.97 \%$ have access to irrigation facilities. The findings further revealed that the mean household commercialization index (HCI) was $74.81 \%$ and the specific HCI for the selected vegetable crops; tomato, okra and cowpeas were $74.92 \%, 72.96 \%$, and $74.84 \%$ respectively. The results from the Tobit regression model revealed that commercialization of horticultural crops is influenced by the age of the farmer, farming experience, type of land acquisition, the quantity of crop produced, group membership, total variable costs, total farm revenue, and access to irrigation facilities. The finding revealed that the age of a farmer, types of crop produced, type of land acquisition, and group membership are negatively significant whereas, farming experience, total variable costs, total farm revenue, and access to irrigation facilities are positively significant. The study suggests that further evaluation of the factors influencing the commercialization of indigenous and exotic vegetables would be required in rural and peri-urban settings of South Sudan. This study provides an insight for policymakers to formulate appropriate policies that can promote domestic production and accelerate the transition of smallholder farmers from subsistence to the market-oriented production system.

Keywords: Commercialization, Horticultural crops, Peri-urban areas, smallholder, Tobit regression model

DOI: $10.7176 / \mathrm{JESD} / 12-14-05$

Publication date:July $31^{\text {st }} 2021$

\section{Introduction}

Commercialization of agricultural food crops is one of the trending global agendas, which aimed at improving the economic welfare of smallholder farmers within the food systems. Nevertheless, commercialization is widely considered one of the best approaches that could help world governments to achieve standard development goal of eradicating hunger, poverty and ensuring food security for all. The commercialization of agriculture is often viewed as an appropriate alternative and leverage point for smallholders to increase their household income while contributing to economic growth and development (Muriithi \& Matz, 2014).

In South Sudan, agriculture is still at its rudimentary level and is characterized as subsistence, however, it accounts for $80 \%$ of the total employment mainly in rural and peri-urban areas (Diao et al., 2012). Like any other developing countries, smallholder farmers are the major actors in the agricultural sector and most of the farmers in South Sudan are practicing subsistence agriculture (UNDP, 2012). Because of the subsistence nature of agriculture, the commodity market share is very low. Therefore it requires a transformation of agricultural production from subsistence to a market-oriented farming system by linking farmers to the market through commercialization to improve household income while reducing destitution level among smallholder farmers (Tufa et al., 2014).

The commercialization of horticultural crops offers potential opportunities for smallholder farmers in South Sudan to generate incomes that can improve their livelihood (Tizikara et al., 2011). A recent study revealed that the commercialization of horticultural crops is a viable strategy that can enhance the economic welfare of smallholder farm household by increasing their income level (Dembele et al., 2018). It has been emphasized that the commercialization of horticultural crops is one of the persuasive approaches that could generate much-need income for smallholder farmers (Ojiewo et al., 2015).

Nutrition-wise, horticultural crops such as vegetables are the most important sources of micronutrients for a human being. They contain the highly needed elements for a healthy body. Vegetables provide a variety of 
benefits that include nutritious food and income for smallholder farm households (Joosten et al., 2015). Through commercialization, smallholder farm households can have an opportunity to increase their income by selling surpluses to the market. However, due to myriad challenges facing smallholders in agricultural sectors, their participation in the output market is not observed. Commercialization of agriculture in South Sudan could be realized by understanding the factors that influence the potentials of smallholder to venture into the marketoriented production of vegetables.

\section{Empirical Literature}

Empirical studies have shown that crop commercialization among smallholder farming household has a crucial role in transforming the wellbeing of low-income agrarian economies. It also serves as a mean to ensuring food security and nutrition as well as increasing household income (Olanrewaju et al., 2016). Over the past few years, many scholars have used various methods to ascertain the significant factors that influence the commercialization of agriculture being cereal crops or horticultural crops.

Using household commercialization index and Tobit regression analysis, Olanrewaju et al., (2016) in their study assessed crop commercialization among smallholder farming households in Southwest Nigeria. They found that crop commercialization for three different crops (maize, cassava, and yam) vary significantly among different farmers across different areas. The results of the specific crop commercialization index have shown that cassava among other crops is the propelling crop for commercialization in the study area. The Tobit regression model results indicated that age, gender, level of education, household size, membership of an association, farm size, access to credit, distance to the market, farm, and off-farm income, are statistically significant in determining the extent of crop commercialization among smallholder farmers.

These findings were also in line with previous results of Omiti et al. (2009), which affirm that distance to the market is a major factor that influences the intensity of market participation among smallholder farmers. It is observed that the extent of crop commercialization among smallholder farmers was comparatively high with significant variations in a different type of crops among farm households. The study, therefore suggests that farmers should increase farm size to increase agricultural production. Nevertheless, governmental institutions are recommended to provide institutional supports such as credit facilities and input subsidy to smallholder farmers to encourage and accelerate the commercialization of food crops.

In a separate study conducted in the Tigray region of Ethiopia, Hailua et al. (2015) evaluated factors affecting the intensity of crop commercialization and its impact on the livelihood of smallholder farmers. The results of the study revealed that the distance to the market and frequency of access to extension services are important variables in the commercialization process. The results obtained from the propensity score matching model (PSM) further revealed that family size, shortage of family labour, cost of farm inputs, distance to market, as well as crop pests and diseases are negatively affecting the intensity of crop commercialization. Furthermore, the findings indicated that the farming community had shown strong interest in transforming subsistence farming to market-oriented and commercialized agriculture. The study opined that the role of government is very crucial to boost rural infrastructure development, rural institutions capacity building and create awareness on the benefits of producing market-oriented products.

Using a Tobit regression model Dube \& Guveya (2016) in their study to evaluate determinants of agriculture commercialization among smallholder farmers in Zimbabwe, found that the mean household commercialization index (HCI) was 0.28 , which shows that the sampled households are highly subsistence. The findings further revealed that the size of the household, availability of draft power, livestock ownership, and access to irrigation, agricultural training, and distance to the market were statistically significant and positively influenced commercialization. The study results were reinstated by Kahenge et al. (2019) findings, which revealed that household size; livestock ownership and distance to the market are the major factors influencing crop commercialization. Besides, the number of household members with secondary education and communal tenure was found to negatively influence the commercialization of agriculture. The authors recommended for the government to promote the commercialization of smallholder agriculture through the provision of extension services such as training farmers to realize the benefits of commercializing farming while equipping them with marketing and negotiation skills.

In a separate study conducted in Kenya, Muriithi (2015) applied descriptive statistics and multiple regression analysis to study smallholder horticultural commercialization on gender roles and implications for household wellbeing. The empirical results indicated that female participation in the commercialization of vegetables is positively related to their membership in farmer groups, education level, ownership of assets, and business access. The findings further revealed that the share of revenues from the sale of export market vegetables managed by female members of the household is positively influenced by total land cultivated, access to extension services, and the number of children attending school. Therefore, the policy implication of the study was that the development geared towards commercialization of agriculture emphasized gender inclusion in the selection of agricultural commodities. Such an approach provides a possibility to observe the role of gender 
(both men and women) in identifying commodity preferences at different stages of the supply chain.

In the past few years, Ochieng et al. (2015) stressed a lot on the use of propensity score matching method to evaluate the effect of commercialization of bananas and legumes on household food security in the Great Lakes region of central Africa. They found that commercially oriented farmers have more diverse diets than noncommercially oriented ones. They further suggested that the commercially oriented farmers could have more purchase power to purchase other foods that could supplement their production. The results further revealed that the household dietary diversity could significantly increase for households that participate in commercialization and subsequently reduce the numerous coping strategies adopted at the time of food deficit. The study, therefore, pointed out alternative options for the realization of the benefits of commercialization. The need to improve socio-economic conditions of the smallholder farmers by establishing well structured and operational market centres, providing access to market information as well as education to the smallholder farmers were prioritized for policy attention.

Although the authors suggested that commercialization have a significant impact on household food security, the study was aggregated in nature. Therefore, this limitation could be overcome by carrying out a country-specific study on the effect of the commercialization of horticultural crops on the household income in Juba, South Sudan to inform the policymakers appropriately.

To date, several studies have used a variety of methods to determine factors influencing the commercialization of crops among smallholders. In a study conducted in Gemechis District, West Hararghe zone in Ethiopia, Tufa et al. (2014) used a double-hurdle model to evaluate determinants of commercialization of horticultural crops among smallholders. The results of the probit regression model of the first hurdle revealed that gender, distance to the market, and cultivated land play a significant role in smallholder commercialization decisions. By using a similar method, Osmani \& Hossain (2015) on their study found that farm size, household size and on-farm income were statistically significant factors triggering participation of smallholder farmers in the output market.

On the other hand, the results of the truncated regression model of the second hurdle showed that the level of education, household size, and access to irrigation, livestock ownership, and distance to the market are the key determinants of the extent of commercialization. They further argued that education increases the ability of farmers to gather and analyze relevant market information, which would improve their ability in terms of better formulation and the execution of farm plans, and acquiring better information to improve their marketing performance. The study recommends that there is a need for designing appropriate intervention mechanisms on the key determinants of commercialization to improve the performance of horticultural crop commercialization.

Using Heckman two-stage approach, Din et al. (2017) analyzed the determinants of commercialization and its impact on the welfare of smallholder rice farmers in Malakand, Pakistan. The study findings showed that the gender of the respondent, age of the respondent, number of family members, vocational training, and farm size were the major determinants of market participation. Their findings were consistent with Mwema \& Crewett (2019), who used the double hurdle approach and found that the farm size and household size have a positive influence on the extent of commercialization. Furthermore, the results indicated that off-farm income, access to credit, and on-farm income were important factors significantly influencing the welfare of the household. The authors recommended market participation could be improved through the provision of subsidized prices for farm produce, cold storage facilities, and the introduction of new technologies. Although the authors appreciate the findings obtained, the study was too broader in the scope in the sense that it mainly focused on the overall effect of commercialization on the general welfare of the household. Therefore, this study overcame these limitations by analyzing the effect of the commercialization of the selected horticultural crops on household income.

In summary, a better understanding of the various factors influencing the commercialization of agriculture is one of the key strategies to unmask the hurdles in the commercialization of horticultural crops. Evidence from various studies has identified major determinants of commercialization (Din et al., 2017; Dube \& Guveya, 2016; Olanrewaju et al., 2016; Hailua et al., 2015; Muriithi, 2015; Tufa et al., 2014) and linked them to socioeconomic and institutional factors. These determinants include the age of the household respondent, gender, level of education, household size, group membership, farm size, market distance, livestock ownership and access to irrigation. Although various factors were identified as the main impediments to commercialization, their influence on smallholder farmer's decision to participate in the output market might not be equally the same across different settings.

The study was conducted in Juba, the capital city of the Republic of South Sudan and the administrative city of Central Equatoria State. Juba is the political, social and economic hub of South Sudan with an estimated population of 392,525 persons (FAO/WFP, 2019). The city is located to the west of White Nile at $31^{0} 5^{\prime}$ East and 
$4^{0} 8^{\prime}$ North. It is one of the busy cities in the country with a variety of business undertakings. Due to its strategic

position in the country it became the most important market for food commodities including horticultural crops (the vegetables) such as tomatoes, cabbages and others. The study was carried out in three peri-urban areas of Juba, which include Gezira Kondokoro, Gomba Shirkat, and Lologo. These areas were selected from three subcounties of Gondokoro, Rajaf East and Rajaf West respectively and are located at a latitude of $30^{\circ} 8^{\prime}-\mathbf{3 1}^{\mathbf{0}} \mathbf{6}^{\prime}$

East, and a longitude of $4^{0} 7^{\prime}-4^{0} 9^{\prime}$ North. The study sites were selected purposely because vegetable farming is

the main undertaking among smallholder farming households. Nevertheless, the land is suitable for vegetable production and with easy access to the water source. In addition the farming households in these selected areas are the local suppliers of vegetables to the urban setting.

\section{Sampling Technique}

The study was carried out using primary data collected from a random sample of smallholder farmers who grow vegetables in Peri-urban areas of Juba. A multi-stage sampling technique was applied to generate the sample size suitable for the study. In the first stage, three sub-counties in Peri-urban areas were selected purposively because they are considered as the supply units for food crops to the city. In the second stage, a randomized sampling technique was applied to select the desired number of respondents. At this stage, the desired sample size was determined by the sampling technique adopted from Anderson et al. (2007). The formula shown in the equation below is universally applicable for determination of a sample size when the population of the target individuals is unknown.

$$
\mathrm{n}=\frac{\mathrm{pqz} z^{2}}{\mathrm{e}^{2}}
$$

\section{Data collection}

Data were collected using semi-structured questionnaires and were analyzed using descriptive statistics such as frequencies, percentages, mean, standard deviation, and household commercialization index (HCI). A pre-test interview, which takes into account $10 \%$ of the total target respondents, was conducted in a different location apart from the target area of study to check for suitability and reliability of the instrument.

\section{Data analysis}

The household commercialization index (HCI) was used to determine whether farmers in Juba are fully subsistence or are partially commercializing. And the crop-specific commercialization index on three selected vegetable crops was computed. The model specification for household commercialization index (HCI) is:

$\mathrm{HCI}_{i}=\left(\frac{\text { Gross value of horticultural crops sales per season }_{\mathrm{j}}}{\text { Gross value of selected horticultural crops output per season }_{\mathrm{j}}}\right) \times 100$

The HCI for specific horticultural crop produced and sold was calculated using the following formula.

$\mathrm{HCI}_{\text {Tomato }}=\left(\frac{\text { Gross value of tomato sales per season }}{\text { Gross value of total tomato output per season }}\right) \times 100$

$$
\mathrm{HCI}_{\text {Okra }}=\left(\frac{\text { Gross value of okra sales per season }}{\text { Gross value of total okra output per season }}\right) \times 100
$$

$$
\mathrm{HCI}_{\text {Cowpeas }}=\left(\frac{\text { Gross value of cowpeas sales per season }}{\text { Gross value of total cowpeas output per season }}\right) \times 100
$$

The Tobit regression model was then run in the STATA computer program to determine factors influencing the commercialization of selected horticultural crops. The Tobit model was chosen over the binary Logit model because its estimation assumes that both the decision to commercialize and the intensity of commercialization are jointly determined with the same variables. Although the ordinary least squares (OLS) model may also be applicable for the analysis, the study has adopted the Tobit regression model because OLS regressions yield bias estimates of the parameters. The model can be specified as:

$$
y_{i}^{*}=\beta_{0}+\beta_{i} X_{i}+\varepsilon_{i}
$$

where $y_{i}^{*}$ is the ratio of selected horticultural crops sales to output produced for ${ }^{i \text { th }}$ farmer (HCI), $\beta$ is a vector of parameter to be estimated, $\mathrm{X}$ is a set of explanatory variables assumed to determine commercialization of horticultural crops, and $\varepsilon_{i}$ is the error term.

$\varepsilon_{i} \approx N\left(0, \sigma^{2}\right), y_{i}^{*}$ denotes a latent variable which is only observed for the values greater than zero and censored otherwise. The observed $\mathrm{y}$ is defined by the following equation. 


$$
\begin{aligned}
& y_{i}=0 \text { if } y_{i}^{*}=\beta_{0}+\beta_{i} X_{i}+\varepsilon_{i} \leq 0 \\
& y_{i}=\beta_{i} X_{i}+\varepsilon_{i} \text { if } y_{i}^{*}=\beta_{0}+\beta_{i} X_{i}+\varepsilon_{i}>0
\end{aligned}
$$

A zero value of $y_{i}^{*}$ is observed when a smallholder farmer has no surplus to sell but has access demand of the commodities. While $\mathrm{y}_{i}^{*}=100$ if household sell all outputs

\section{RESULTS AND DISCUSSION}

\subsection{Descriptive Statistics Results}

4.1.1 Summarized statistics for dummy and categorical variables used in the study

Based on the results presented in table 4.1, the major actors in the horticultural subsectors in Juba are women with a proportion of $77.48 \%$ of the total respondents interviewed. The gender disparity in this particular enterprise could partly be associated with the fact that men in Peri-urban areas tend to engage in non-farm activities more than women, hence leaving the major roles of farming to the women.

About $60.93 \%$ of the total sample interviewed reported having access to education. This is attributed to the displacement effect of most of the respondents interviewed since some of them were displaced persons living deep in the villages where schools are not provided. Furthermore, $37.09 \%$ of the respondents have a primary level of education, while $39.07 \%$ have informal education. This indicates that the illiteracy level is very high, which reflects that farmers in Juba are not sufficiently endowed with human capital that can accelerate their understanding of good agricultural practices.

The results further revealed that $99.34 \%$ of the total households interviewed reported farming as their main occupation. However, only $32.65 \%$ of the interviewed households have access to land ownership (a small proportion owned the land for farming). The majority of farmers $65.31 \%$ acquire farming land through renting. The result also showed that $65.56 \%$ of vegetable crops grown by smallholder farmers in Juba are okra and cowpeas under mixed cropping. The study further revealed that tomato is the least produced among other vegetables due to its production constraints. Only a few farmers who have acquired a reasonable level of education incorporate tomato in their enterprise with other crops such as okra and cowpeas.

About $54.30 \%$ of the total farmers reported that they obtained their seeds from their local markets while a proportion of $35.76 \%$ reported that they purchased their seeds from the Agro-vet shops. Only $9.96 \%$ of the total interviewed households reported that they receive their seeds from NGOs. The proportion of those getting their seeds from Agrovet shops compared to local markets is relatively small. This is because the prices for seeds at Agro-vet shops are expensive compared to the local markets. Hence, the majority of the farmers prefer to source their seeds from the local markets regardless of the quality issues.

From the total sample of farmers interviewed, $60 \%$ of the farmers reported having successfully acquired credit in form of loan from other sources such as relatives, friends and shop owners nearby. There is a lack of institutional support, whereby banks or micro-finance institutions could offer loans to the farmers to facilitate farming activities (Museli, 2017). Availability of institutional support could render smallholder farmers an opportunity to increase their production capacities to meet market demands.

Similarly, most of the farmers interviewed $(96.69 \%)$ reported a lack of access to the market information, which includes information on the prices of inputs and outputs. Market information is one of the most important requirements in a farming enterprise. Market intelligence informs farmers about the prevailing market prices and availability of potential buyers, thereby facilitating farmer's decisions on the quantity and quality of crop to produce. The information asymmetry (lack of information) has a negative impact on the income of smallholder farmer. It brings about exploitation to the smallholder farmers through the opportunistic behaviour of the middlemen. The presence of middlemen (brokers) in vegetable enterprise reduces the marginal return of the farmer especially those farmers selling their produce at the farm-gate prices. In this case, the smallholder farmers in Juba do not have the opportunity to reap the benefit derives from selling farm produce at retail prices.

The findings further indicated that $74.17 \%$ of farm households interviewed do not belong to any social group. This implies that the knowledge transfer or sharing would not be easy among smallholder farmers, and therefore they might not obtain the benefits associated with being a member of any social or farming group. The group membership in the agricultural sector offers a wide range of benefits that includes the ability to learn new things, access credit facility, and obtain strong bargaining power as well as gaining easy access to extension services. It is evident in some part of the world that the formation of farming groups has contributed a positive impact on the welfare of smallholder farmer (Moranga, 2016). The farming groups or cooperatives are widely used by agriculture extension providers and NGOs in form of Farmer's Field School (FFS) to impart the necessary knowledge required to enhance farmer's productivity. The farmer's field school is a participatory approach through which farmers participate practically and theoretically in knowledge transfer. A farmer who is a member of the farming group is likely to acquire new skills and technologies necessary to improve farm productivity.

Over half of the interviewed farmers, $54.97 \%$ reported having access to irrigation facilities. This group of 
farmers obtained their irrigation facilities (being watering cans, treadle and motor pumps) from the local markets and organizations dealing with food security projects. The other proportions of farmers $45.03 \%$ rely on rainfall for crop production, hence resulting in low or no production during dry seasons.

Table 4.1: Descriptive statistics for dummy and categorical variables used in the study

\begin{tabular}{|c|c|c|}
\hline Variable & & Percentage $(\%)$ \\
\hline \multirow[t]{2}{*}{ Gender } & Male & 22.52 \\
\hline & Female & 77.48 \\
\hline \multirow[t]{2}{*}{ Access to education } & Yes & 60.93 \\
\hline & No & 39.07 \\
\hline \multirow[t]{4}{*}{ Education level } & Informal & 39.07 \\
\hline & Primary & 37.09 \\
\hline & Secondary & 19.87 \\
\hline & University & 3.97 \\
\hline \multirow[t]{2}{*}{ Household occupation } & Yes & 99.34 \\
\hline & No & 0.66 \\
\hline \multirow[t]{2}{*}{ Land Ownership } & Yes & 67.55 \\
\hline & No & 32.45 \\
\hline \multirow[t]{3}{*}{ Type of land acquisition } & Seasonal contract & 2.04 \\
\hline & Rented & 65.31 \\
\hline & Others & 32.65 \\
\hline \multirow[t]{6}{*}{ Type of crop } & Tomato only & 0 \\
\hline & Okra only & 6.62 \\
\hline & Cowpeas only & 9.93 \\
\hline & Tomato and okra & 0.66 \\
\hline & Okra and Cowpeas & 65.56 \\
\hline & Tomato, Okra and Cowpeas & 17.22 \\
\hline \multirow[t]{2}{*}{ Access to credit } & Yes & 60 \\
\hline & No & 40 \\
\hline \multirow[t]{2}{*}{ Access to market information } & Yes & 3.31 \\
\hline & No & 96.69 \\
\hline \multirow{2}{*}{ Group membership } & Yes & 25.83 \\
\hline & No & 74.17 \\
\hline \multirow[t]{2}{*}{ Access to irrigation facilities } & Yes & 54.97 \\
\hline & No & 45.03 \\
\hline
\end{tabular}

4.1.2. Summarized statistics for continuous variables used in the analysis

According to the findings shown in Table 4.2, the average age of the farmer involved in vegetable farming is approximately 34 years old (33.67). This implies that the horticultural subsector is predominantly occupied by youth. Even though older farmers are considered more experienced than the youth, the young farmers surpass their participation in the vegetable enterprise. This further indicates that most of the farmers engaged in a vegetable enterprise are youth within the economically productive age bracket with high potential to participate in numerous livelihood activities including farming enterprises (Nyaruwata, 2019). The fact that vegetable farming is a labour-intensive enterprise rendered youth an opportunity to be the major actors in the horticultural subsector.

The average household size was seven persons per household (7.42), which implies that family labour is common among smallholder farmers in Juba. In addition, the larger family size tends to rely on the quantity of farm output for subsistence. This could be one of the possible reasons why some farmers do not participate in the output market due to a lack of surplus to sell. Although larger household size provides an advantage for smallholder farmers to implement the labour-intensive enterprise, there is also a likelihood that such household would engage in subsistence farming. Furthermore, the finding revealed that the average number of years spent by a farmer in vegetable farming in Juba is approximately twelve years (11.96 years). This indicates that most of the farmers have fairly been undertaking vegetable farming as the main occupation. It also shows that farmers in Peri-urban areas of Juba have long been practicing vegetable farming as their main undertaking since the country gained its independence. This could also indicate that most of the farmers are either displaced persons or returnees who settled there before or after independence.

The study also found that the average off-farm and on-farm incomes are 1,139.27 and 26,611.92 SSP respectively. This shows that farmers in the study area drive more income from farming activities compared to off-farm employment. This result is consistent with the finding of Melese et al. (2018) who found that farmers who participated in the marketing of their farm produce receive a higher income than the non-participants. Furthermore, the findings of the study revealed that the mean farming experience of farmers in the study area is 
roughly 12 years (11.96 years). It is hypothesized that farming experience is important if the farmers were to improve the degree of commercialization, as a more experienced farmer is likely to commercialize because of the endowed knowledge and skills Agwu (2013).

The average farm size for smallholder farmers in Juba is about one acre $(0.80)$. The results indicate that most of the farmers are small scale mainly producing for subsistence purpose. These findings support the notion that there is no standardize acreage of land described to characterize whether a farmer is a smallholder or not. The term smallholder is therefore a contextual term, which varies across the countries and regions of the world. Land is one of the crucial factors of production and the most vital resource for crop production (Opondo \& Owuor, 2018) that could be a constraining factor for commercialization. The average quantity produced and quantities sold is 87.90 Kilograms and 69.70 Kilograms respectively with the mean household commercialization index of $74.81 \%$ (Table 4.2) implying that the sampled households are commercializing their produce. Moreover, on average the farm revenue is 84,399.29 South Sudanese Pounds (SSP) while the mean total variable cost of production is 6,983.44 South Sudanese Pounds. The low total variable cost can be attributed to the fact that most of the farmers in the study area depend extensively on family labour for farm activities. Hence, resulting in a reduction of the total variable cost to a minimum amount as compared to those with smaller household size.

Although there were some outliers in the quantity of crop produced and total variable costs, it could be argued that some farmers were badly affected by flood and diseases in the previous cropping season resulting to low or zero yield. On the other hand, farmers who were not affected had more harvest. Similarly, farmers endowed with large family labour were able to cut the costs. From this standpoint, the presence of outlier values is attributed to farmer's endowment and corresponding environmental factors. Market distance and market prices were also important variables in crop commercialization. The results of the study revealed that the mean distance to the output market is 5.31 kilometers. This implies that the distance to the input-output market is not a major constraint to the farmers in Peri-urban areas of Juba. However, the poor condition of the road with insufficient packaging materials might be the constraining factors for farmers willing to sell their farm produce to the competitive markets. The farmers located far away from the market are less likely to sell their farm produce to the market. Due to the greater distance to the market, they are likely to more costs. This finding corroborates with Opondo \& Owuor (2018) who argued that farmers living far away from the output market are likely to experience a reduction in their marketing activities. This in return drives the local producers to sell their farm produce at farm gate price. Furthermore, the study revealed that the average prevailing market prices for tomato, okra, and cowpeas in the previous year of harvest were 651.67; 1,362.93, and 956.05 South Sudanese Pounds respectively.

The mean household commercialization index (Mean HCI) among smallholder farmers involved in vegetable enterprise was found to be 74.81. This finding implies that farmer above the computed mean, are highly commercialized while those below the mean are subsistence producers who grow vegetables for domestic consumption. On the other hand, the statistical results indicated that farmers who participated in the output market have a bigger share of the farm products sold to the market to earn more income. Additionally, the finding reveals that the specific crop commercialization index was different among smallholder farmers. The results in table 4.2 above indicate that the mean commercialization index for tomato was $74.92(0.7492 \%)$, Okra was $72.96(0.7296 \%)$, and Cowpeas was $74.85(0.7485 \%)$. This implies that cowpea is the major crop that drives the commercialization of vegetable crops among smallholder farm households in the study area. Although the commercialization index for tomato is greater than cowpea, it could be possibly explained that few farmers who grew tomato in the previous cropping season sold all the quantity produced to the market. Hence, the mean value of the commercialization index for tomato has increased due to the small number of farmers producing and selling tomato. 
Table 4.2 Descriptive statistics for continuous variables used in the analysis

\begin{tabular}{lll}
\hline Variable & Mean & Std. Dev. \\
\hline Age & 33.67 & 10.02 \\
Household size & 7.42 & 2.56 \\
Farming experience & 11.96 & 8.23 \\
On-farm Income & 26611.92 & 41930.84 \\
Off-farm Income & 1139.27 & 5470.46 \\
Farm size & 0.80 & 0.93 \\
Quantity of crop produced & 87.90 & 104.32 \\
Quantity of crop sold & 69.70 & 100.60 \\
Market Price for tomato & 651.67 & 0 \\
Market price for Okra & 1362.93 & 0 \\
Market price for Cowpeas & 956.05 & 0 \\
Distance to the market & 5.31 & 2.92 \\
Total farm revenue & 84399.29 & 135433.7 \\
Total variable cost & 6983.44 & 13521.04 \\
HCI & 74.81 & 18.90 \\
HCI for Tomato & 74.92 & 18.89 \\
HCI for Okra & 72.96 & 19.64 \\
HCI for Cowpeas & 74.85 & 21.51 \\
\hline
\end{tabular}

\subsection{Factors influencing commercialization of horticultural crops}

Using the Tobit regression model with the mean household commercialisation index (HCI) of 74.81, the results from the analysis of data obtained from a sample of 151 respondents presented in table 4.3 shows that age of the respondent, farming experience, type of land acquisition, a quantity of crop produced, group membership, total variable costs, total farm revenue and access to irrigation facilities have a significant influence on the commercialisation of horticultural crops.

The results obtained from the Tobit regression model in Table 4.3, indicate that age of the respondent is negatively and statistically significant at a $10 \%$ significant level. This shows that if the age of the farmer increases by one year, the extent of commercialisation of horticultural crops decreases by 0.3221 . This suggests that as the farmer grows old, the energy devoted to farming activities decreases hence the farmer may only produce for subsistence purposes. Furthermore, the decrease in commercialisation with an increase in age could be explained that as farmers grow older, they tend to have more dependents putting more pressure on them to produce mainly for subsistence thus reducing the chances of commercialising. This could also be attributed to the fact that younger farmers regardless of few years of experience in farming tend to play a crucial role in the agricultural value chain. Because of the age advantage, youth involved in the horticultural subsector are liable to increase their output level, hence producing more for subsistence and surplus to the market. This study finding corroborates with Melese et al. (2018) who found that the age of the farm household negatively influences the decision of the farmer to commercialise. Similarly, Olenrewaju et al. (2016) reported the same results where they found that the age of the farmer is one of the crucial factors that influences commercialisation among smallholder farmers.

The farming experience was found to be positively and statistically significant at a $1 \%$ significant level. This implies that if the level of farming experience increases by one year, the decision to commercialise increases by 0.61 units holding other variables constant. A possible explanation could be a farmer with more years of farming is likely to have higher chances of acquiring various skills such as marketing skills that could contribute to the increased level of commercialisation than those with few years experience in farming. Moreover, those farmers who have spent many years in farming tend to know more about the suitable conditions and timing for farming thus helps them to time market peaks when the demand for the product is high. Therefore, the more experience gained over a long period of farming is highly significant to influence the amount of farm output that a farmer can produce which in return determines whether a farmer can specialize in subsistence agriculture or commercialised agriculture. This study finding corroborates that of Agwu (2013) who found that farmers with more years of experience in farming are likely to engage in the commercialisation of their farm produce due to endowed skills and expertise.

The study also considered land in the analysis as one of the influential factors of production and the type of land acquisition determines the number of acres a farmer can allocate for farming. The results showed that type of land acquisition negatively influences farmers' decision to commercialise at a $1 \%$ significance level. This study suggests that if the amount of land acquired through rent and others (sharecropping) increase by one acre, the decision of the farmer to commercialise decreases by 24.99 units and 22.06 units respectively. The study suggests that a higher proportion of the farmers $65.31 \%$ acquired the land through renting and a few of them 
$32.65 \%$ acquired land from their friends or relatives as given only for farming. This is because most of the farmers in those Peri-urban areas are either internally displaced persons or returnees. Because of the importance of land, most of the farmers tend to rent the land from the host communities for farming purpose although some of the farmers have access to land through an offer by their friends or relatives and few have the land title deeds.

The finding concurred with Mbiti et al. (2021) who found that the proportion of land allocated for vegetable production significantly influences the commercialisation of vegetables in Kenya. The findings further revealed that the quantity of crop produced per cropping season is negatively and statistically significant at a $1 \%$ significance level. This implies that the decision to participate in the output market (commercialisation) depends on the number of crops that a farmer could produce. For instance, if the quantity of crop produced (the output quantity) per cropping season decreases by one unit $(\mathrm{Kg})$ the level of commercialisation of the crop under consideration decreases by 0.66 .75 units. This means that the higher the output quantity of the selected crops per cropping season, the higher the likelihood that a farmer will engage in the commercialisation of the selected horticultural crops. This finding is in line with previous studies of Melese et al. (2018) who found that an increase in onion, tomato and mango productions increases the probability of farmers engaging in commercialisation.

Additionally, the study indicates that group membership, which is referred to as the affiliation of the farmer to any type of agricultural group, is key variable influencing commercialisation. In this study, group membership was found negatively and significantly associated with the farmer's decision to commercialise at a $5 \%$ significance level. This relationship could be explained by the fact that if the farmer decided not to be a member of any social group, the probability to participate in the marketing of their produce decreases by 8.41 units. This implies that being in any agricultural group increases the opportunity for marketing farm produce. A farming household that has joined any type of group within the agricultural group have higher chances of acquiring new skills from the member group, hence increasing opportunities to engage in commercialised agriculture. A possible explanation for this could be that being in a group increases the opportunity of accessing the information on market-related issues thus lowers the transaction costs. The finding concurred with the results of Olenrewaju et al., (2016) who found that group members have a significant influence on farmer's decision to commercialise. However, the findings disagree with Muriithi (2015) in her study on the role of gender in smallholder commercialization of horticultural in Kenya. The author found that being a member of a farmer group positively influences the commercialisation of horticultural crops.

The total cost incurred by the farmer in the vegetable enterprise, which includes the cost of inputs, labour and transportation was also hypothesized to influence the level of commercialisation. The total variable cost was found to be positively and significantly influencing the decision of the farm household to commercialise at a $1 \%$ significance level. This implies that if the farm total variable cost of production increases by one SSP, the decision to commercialise increases by 0.0011 units. This could be possibly explained that the farmer will opt for selling farm produce to recover the cost of production and to earn profit as well. However, Hailua et al. (2015) results contradict this finding where the cost of farm inputs was found negatively influencing commercialization decision among smallholder farmers. This contradiction in the study could be imputed to the variation in the type of farm inputs and the number of inputs used across individual farmers. For example, the majority of farmers in Juba have reported that they used family labour to implement farm activities, and they source their seeds from the local market at reasonable prices. Moreover, in most cases, farmers in Juba do not use fertilizers and pesticides that can also account for decreased total variable cost among smallholder farmers.

Regarding total farm revenue, the study findings revealed that the total farm revenue is positively influencing the decision to commercialise at a 1\% significant level. For instance, the result showed that if the total farm revenue increases by one South Sudanese Pound, the decision of the farmer to commercialise increases by 56.39 units. This implies that the more the income (revenue) the farmer receives from sales of farm output, the higher the chances of engaging in commercialisation. Consistently, Osmani \& Hossain (2015) also found that on-farm income from the sales of farm produces significantly influences the decision of the farmer to participate in the output market.

The other outcome that emerged from the analysis is the farmer's access to irrigation facilities, which determines whether a farmer will produce during the off-season. Farmers who have access to irrigation facilities are capable of producing during the dry season and hence tends to benefit from the higher prices offered as a result of short supply in the market. From the study findings, access to irrigation facilities was found positively significant at a 5\% significance level.

This implies that if the chance of accessing irrigation facilities increases by one unit, the likelihood of the farmer commercialising increases by 7.82 units. Lack of farmer access to irrigation facilities is notably the main impediment for smallholder farmers in juba to continue farming during the off-season. The result corroborates Tufa et al. (2014) findings where access to irrigation facilities was found significantly influencing the decision of smallholder farmers in Ethiopia to take part in the commercialization of horticultural crops. 
Table 4.3: Parameter estimates of the Tobit model

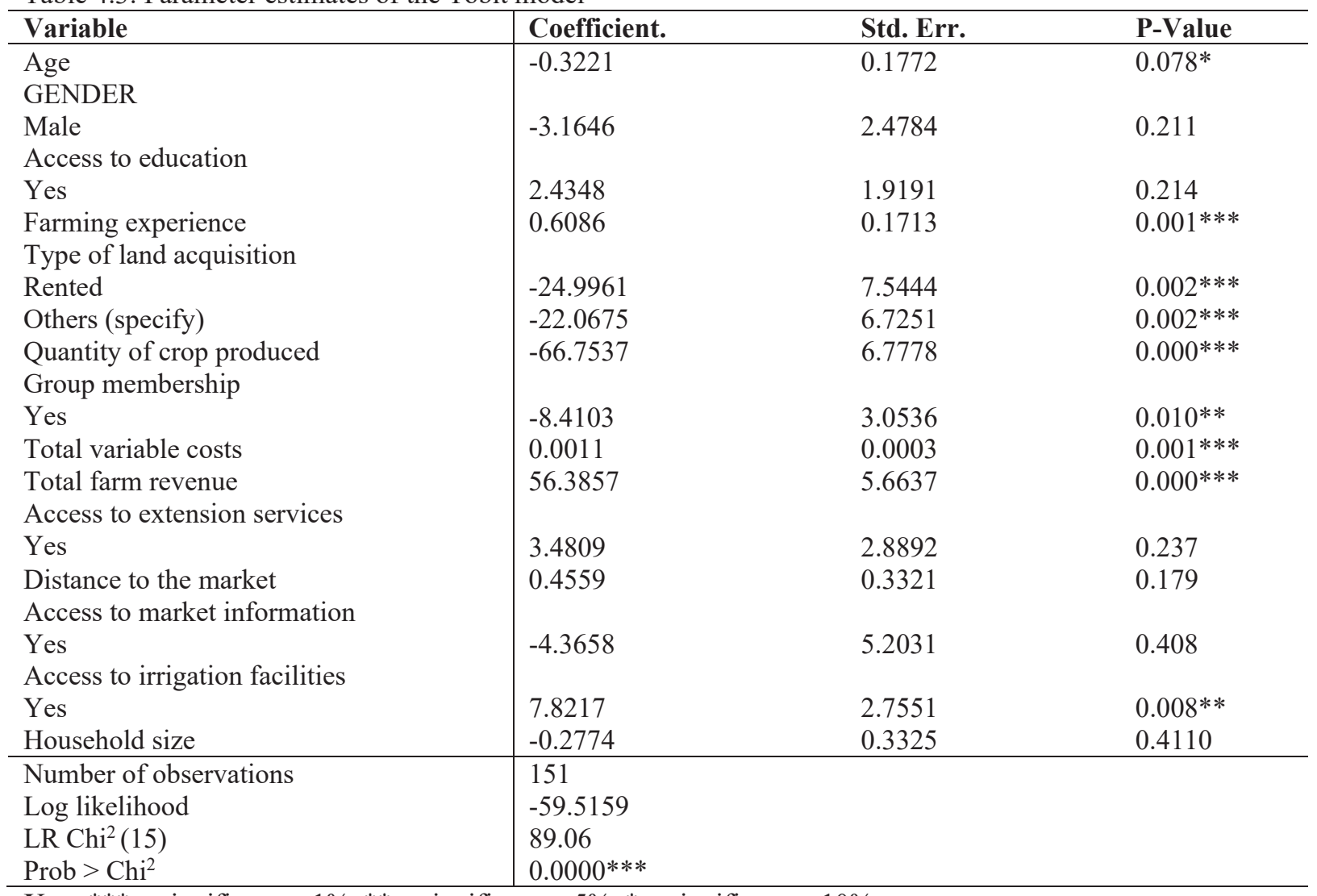

Key: $* * *=$ significant at $1 \%, * *=$ significant at $5 \%, *=$ significant at $10 \%$

\section{CONCLUSIONS AND POLICY IMPLICATIONS}

This study examined the factors influencing commercialization of horticultural crops among smallholder farm households in Juba, South Sudan. Based on the findings of this study, the average household commercialization index for smallholder farmers engaged in vegetable enterprise is $74.81 \%$, which shows that households producing vegetables sell most of their farm produce to the market. However, it was noted that the commercialization of horticultural crops is influenced by various socio-economic and institutional factors. The study found that commercialization is significantly influenced by the age of the farmer, farming experience, the type of land acquisition, the quantity of crop produced, a group membership, total variable costs, total farm revenue, and access to irrigation facilities. Therefore, the findings of the study suggests that the policymakers should accelerate the transformation of agricultural sector by developing appropriate land tenure policies that ensure easy access to farming land and promote the formation of farmer's organization or cooperatives in periurban areas and across the country. Moreover, the government should subsidize agricultural production by providing farmers with irrigation facilities and extension services to enhance productivity of horticultural crops among smallholder farmers. Additionally the national government should develop a framework that promote farmer's access to market information and credit facility.

\section{ACKNOWLEDGEMENTS}

The author acknowledges the financial assistance received from the Centre of Excellence for Sustainable Agriculture and Agribusiness Management (CESAAM) in funding this work. Nevertheless, the contribution provided by academic advisors to improve this manuscript is highly acknowledged.

\section{REFERENCES}

Agwu, N. M., Anyanwu, C. I., \& Mendie, E. I. (2013). Socio-economic determinants of commercialization among smallholder farmers in Abia State, Nigeria (No. 309-2016-5233).

Dembele, K. D., Mshenga, P. M., Owuor, G., Badolo, F., \& Tignegre, J. B. (2018). Economic Analysis and Determinants of Selected Women-Led Vegetable Enterprises Performance in Koutiala and Bougouni Districts, Mali. Economic Analysis, 9(14).

Diao, X., You, L., Alpuerto, V. \& Folledo, R. (2012). Assessing Agricultural Potential in South Sudan-A Spatial Analysis Method. Application of Geographic Information Systems, 139. 
Din, I. U. (2017). Determinants of commercialization \& its impact on the welfare of smallholder rice farmers by using Heckman's two-stage approach.

Dube, L. \& Guveya, E. (2016). Determinants of agriculture commercialization among smallholder farmers in Manicaland and Masvingo Provinces of Zimbabwe. Agricultural Science Research Journal, 6(8), 182-190.

FAO/WFP, (2019). Crop and food security assessment mission to South Sudan. http://www.fao.org/giews/ and http://www.wfp.org/food-security/reports/CFSAM. Retrieved on $8^{\text {th }}$ November 2019.

Hailua, G., Manjureb, K. \& Aymutc, K. M. (2015). Crop commercialization and smallholder farmer's livelihood in the Tigray region, Ethiopia. Journal of Development and Agricultural Economics, 7(9), 314-322.

Joosten, F. J., Dijkxhoorn, Y., Sertse, Y. \& Ruben, R. (2015). How does the fruit and vegetable sector contribute to food and nutrition security? (No. 2015-076).

Kahenge, Z., Muendo, K., \& Nhamo, N. (2019). Factors influencing crop commercialization among soybeans smallholder farmers in Chipata District, eastern Zambia. Journal of agriculture, science and technology, 19(1), 13-31.

Kothari, C. R. \& Garg, G. (2014). Research Methodology and Techniques of New Age.

Krause, H., Fabe, A., \& Grote, U. (2019). Welfare and food security-effects of commercializing African indigenous vegetables in Kenya. Cogent Food \& Agriculture.

M'ithibutu, M. J., Gogo, E. O., Mangale, F. L., \& Baker, G. (2021). An evaluation of the factors influencing vegetable commercialization in Kenya. International Journal of Agriculture, 6(1), 1-19.

Melese, T., Dessie, A. B., \& Abate, T. M. (2018). Determinants of commercialization by smallholder onion farmers in Fogera district, South Gondar Zone, Amhara national regional State, Ethiopia. Journal of Development and Agricultural Economics, 10(10), 339-351.

Moranga, L. O. (2016). Analysis of Factors Influencing Tomato Farmers' Willingness to Adopt Innovative Timing Approaches for Management of Climate Change Effects in Taita Taveta County, Kenya (Doctoral dissertation, University Of Nairobi).

Muriithi, B. \& Matz, J. (2014). Smallholder participation in the commercialization of vegetables: Evidence from Kenyan panel data. Available at SSRN 2405462.

Muriithi, B. W., \& Matz, J. A. (2015). Welfare effects of vegetable commercialization: Evidence from smallholder producers in Kenya. Food policy, 50, 80-91.

Museli, B. M. E. (2017). Understanding socio-economic challenges facing smallholder farmers in Gondokoro, Central Equatoria State (South Sudan). Master's thesis Norwegian University of Life Sciences.

Mwema, C., \& Crewett, W. (2019). Social Networks and Commercialisation of African Indigenous Vegetables in Kenya: A Cragg's Double Hurdle Approach. Cogent Economics \& Finance, 7(1), 1642173.

Nyaruwata, C. (2019). Contribution of Selected Indigenous Vegetables to Household Income and Food Availability in Wedza District of Zimbabwe. ACTA scientific agriculture, 3 (3), 170-188.

Ochieng, J., Knerr, B., Owuor, G. \& Ouma, E. (2015). Agricultural commercialization and household food security: The case of smallholders in Great Lakes Region of Central Africa. In International Conference of Agricultural Economists, Mila, Italy.

Ojiewo, C. O., Tenkouano, A. \& Yang, R. (2010). The role of AVRDC-The World Vegetable Centre in vegetable value chains. African Journal of Horticultural Science, 3.

Olanrewaju Emilola, C., Adenegan Kemisola, O. \& OO, A. (2016). Assessment of crop commercialization among smallholder farming households in Southwest Nigeria. International Journal of Scientific Research in Science and Technology, 2(6), 478-486.

Omiti, J. M., Otieno, D. J., Nyanamba, T. O., \& McCullough, E. B. (2009). Factors influencing the intensity of market participation by smallholder farmers: A case study of rural and peri-urban areas of Kenya. African Journal of Agricultural and Resource Economics, 3(311-2016-5509), 57-82.

Opondo, F., \& Owuor, G. (2018). The Effect of Cassava Commercialization On Household Income of Smallholder Farmers in Arid and Semi-arid Land (Asal), A Case of Kilifi County, Kenya (No. 2058-20185348).

Osmani, A. G., \& Hossain, E. (2015). Market participation decision of smallholder farmers and its determinants in Bangladesh. Economics of Agriculture, 62(297-2016-3664), 163-179.

Schaffnit-Chatterjee, C., Lanzeni, M. L., AG, D. B. \& Hoffmann, R. (2014). Agricultural value chains in SubSaharan Africa. From a development challenge to a business opportunity. Deutsche Bank Research, Frankfurt.

Tizikara, C. \& Lugor, L. G. L. (2011). Post-conflict Development of Agriculture in South Sudan: Perspective on Approaches to Capacity Strengthening.

Tufa, A., Bekele, A., \& Zemedu, L. (2014). Determinants of smallholder commercialization of horticultural crops in Gemechis District, West Hararghe Zone, Ethiopia. African journal of agricultural research, 9(3), 310-319.

UNDP, (2012). Investing in Agriculture for Food Security and Economic Transformation. 
https://www.undp.org/content/dam/southsudan/library/Reports/southsudananotherdocuments. Retrieved on November $8^{\text {th }} 2019$.

World Bank, (2019). South Sudan: Linking the Agriculture and Food Sector to the Job Creation Agenda. 